Western University

Scholarship@Western

Aboriginal Policy Research Consortium International (APRCi)

5-18-2009

\title{
Aboriginal house names and settler Australian identity
}

Sam Furphy

University of Melbourne

Follow this and additional works at: https://ir.lib.uwo.ca/aprci

Part of the Race and Ethnicity Commons

Citation of this paper:

Furphy, Sam, "Aboriginal house names and settler Australian identity" (2009). Aboriginal Policy Research Consortium International (APRCi). 433.

https://ir.lib.uwo.ca/aprci/433 
This article was downloaded by: [University of Western Ontario]

On: 20 December 2012, At: 06:20

Publisher: Routledge

Informa Ltd Registered in England and Wales Registered Number: 1072954 Registered office: Mortimer House, 37-41 Mortimer Street, London W1T 3J H, UK

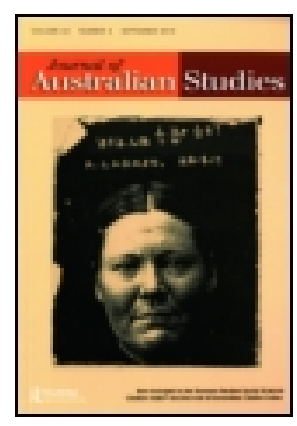

\section{J ournal of Australian Studies}

Publication details, including instructions for authors and subscription information: http:// www. tandfonline.com/loi/ rjau20

\section{Aboriginal house names and settler Australian identity} Sam Furphy ${ }^{\text {a }}$

${ }^{a} \mathrm{PhD}$ at the University of Melbourne

Version of record first published: 18 May 2009.

To cite this article: Sam Furphy (2002): Aboriginal house names and settler Australian identity, J ournal of Australian Studies, 26: $72,59-68$

To link to this article: http:// dx. doi.org/ 10.1080/ 14443050209387738

\section{PLEASE SCROLL DOWN FOR ARTICLE}

Full terms and conditions of use: http://www.tandfonline.com/page/terms-and-conditions

This article may be used for research, teaching, and private study purposes. Any substantial or systematic reproduction, redistribution, reselling, loan, sub-licensing, systematic supply, or distribution in any form to anyone is expressly forbidden.

The publisher does not give any warranty express or implied or make any representation that the contents will be complete or accurate or up to date. The accuracy of any instructions, formulae, and drug doses should be independently verified with primary sources. The publisher shall not be liable for any loss, actions, claims, proceedings, demand, or costs or damages whatsoever or howsoever caused arising directly or indirectly in connection with or arising out of the use of this material. 


\section{Aboriginal House Names and Settler Australian Identity}

\section{Sam Furphy}

During his time as a federal politician and prime minister, Alfred Deakin divided his time between his city residence in Toorak and his holiday retreat at Point Lonsdale. His family had acquired several acres of land on the Bellarine peninsula in 1904 where they had built a federation bungalow called 'Ballara'. The word is probably derived from the Wathawurung word balla for 'elbow', thus 'reclining on elbow' or 'resting place'. ' The name has further significance as another form of 'Ballarat,' which was the electorate Deakin represented in federal parliament. ${ }^{2}$ While at Ballara, Deakin was a keen gardener. John Rickard explains that when toiling on summer evenings his aim was 'to reduce the complex wilderness of teatree to a park-like, though still native prospect, with paths and occasional glades'. 3 This juxtaposition of a native garden and a native name indicates a belief that Aboriginal names were Australian names that suited the natural environment and native flora of Australia. Deakin's son-in-law, Herbert Brookes, subsequently bought an adjacent block at Point Lonsdale, which he named 'Arilpa' (meaning 'moon'). ${ }^{4}$ The Deakins and Brookes also lived next door to each other in Melbourne where, in contrast, the names of their residences were 'Llamarth' and 'Winwick' respectively. It is significant that their city houses in the affluent suburb of Toorak had settler names, while their rustic, coastal, holiday retreats at Point Lonsdale had indigenous names. ${ }^{5}$

This article examines the peculiar phenomenon of the Aboriginal house name. Its chief source of evidence is the wide variety of advice books which, throughout the twentieth century, encouraged Australians to give their house or boat an 'Aboriginal' name. It traces the development of a national (or settler) identity, which appropriated and adapted certain indigenous motifs for mainstream consumption, and argues that Aboriginal house names are a prime example of what has been termed the 'indigenisation' of Australian settler identity.

In recent historiography, the extent to which Aboriginal culture and heritage has been employed to confer Australian national identity has often been considered. David Carter argues that ' $[t]$ he land has been a source of European images of distinctive Australian identity since the nineteenth century. ${ }^{6}$ While Carter argues that the exotic nature of Australia's indigenous flora and fauna is an obvious example of this, he goes on to argue 'the landscapes that work with the full power of nationing are increasingly Aboriginal landscapes. ${ }^{7}$ A similar view has been taken by Tom Griffiths, who argues in Hunters and Collectors that:

Throughout their history-making, Europeans sought to take hold of the land emotionally and spiritually, and they could not help but deny, displace and sometimes accommodate Aboriginal perceptions of place. They were feeling their way towards the realisation that becoming Australian would, in some senses, mean becoming 'Aboriginal'. 8 
Carter and Griffiths recognise the 'nationing' power of Aboriginal culture. Anne McGrath argues that 'white Australians have been involved in a mythological quest to forge relationships with the landscape through literature and legend" and that appropriating Aboriginal place names is one way of achieving the goal of being distinctively Australian. ${ }^{10}$ Bruce Scates discusses representations of Aboriginality in the colonial paper, the Boomerang, and explores the attempt of editor William Lane 'to aesthetise nationalism by appropriating (and re-inventing) Aboriginal motifs and imagery." $"$ Robert Sellick examines the Jindyworobak literary movement of the 1930s and 1940s and identifies the tendency of this group to construct an idealised version of Aboriginality, which is fundamentally aimed at defining an Australian (literary) identity. ${ }^{12}$ Other writers have made similar arguments in a variety of contexts. ${ }^{13}$ The most crucial aspect of all these examples is that 'Aboriginality is performed for the benefit of non-Aboriginal Australia.' 14

Terry Goldie uses the term 'indigenisation' to describe this process. ${ }^{15} \mathrm{He}$ argues that indigenisation is a response to the paradox that, although 'the Aborigine is Other and therefore Alien,' it is also true that 'the Aborigine is indigenous and therefore cannot be alien.' Denis Byrne takes a similar view when he suggests that as with the 'Indianization' of eighteenth-century North American settler identity:

certain aspects of Aboriginal culture were powerfully attractive to a new nation casting around for symbols and emblems of essential Australianness and some of these aspects were admissible. Aboriginal words provided original-sounding place names and were used from the earliest days of the colony. ${ }^{16}$

The reasons behind this 'indigenisation' are complex, but some have argued that it has the effect of pushing Australia's history back beyond 1788. Carter argues that 'the nation's past is pushed backwards so that one of the newest societies on earth is given one of the longest histories.' 17 The incorporation of Aboriginal culture into mainstream Australian culture thus connects Australian identity with the Australian landscape, but at the same time it glosses over the realities of colonisation and invasion.

While examining contested namings in the westem districts of Victoria, Tony Birch argues that:

Houses, streets, suburbs, and whole cities have indigenous names. This is an exercise in cultural appropriation, which represents imperial possession and the quaintness of the 'native'. For the colonisers to attach a 'native' name to a place does not represent or recognise an indigenous history, and therefore possible indigenous ownership. ${ }^{18}$

Birch highlights the marginal status of actual Aboriginal people where naming is concerned, but also elucidates the simplistic and contrived manner in which Aboriginal names have often been appropriated.

Throughout the twentieth century in Australia there have been a significant number of popular publications of lists of Aboriginal words. Some of these provided meanings for the abundance of Aboriginal place names, which can be found on the maps of every state in Australia. They attempted to promote interest in the often forgotten meanings of so many of these place names. Other 
publications provided a list of Aboriginal words (often described as 'euphonious' or 'pleasant sounding') for future use. These publications (which for ease of reference I refer to as 'naming books') have been produced by a variety of individuals and groups and with a variety of professed and underlying motives. A naming book that receives particular attention in this article is Sydney J Endacott's Australian Aboriginal Native Words and their Meanings (1923). Others compiled by Watkin (1914), Kenyon (1930), Cooper (1949), McCarthy (1952), Ingamells (1955), Reed (1965), and Macquarie University (1996) are also considered. The popularity of these publications is evidenced by the many print runs and new editions which most experienced. ${ }^{19}$

A surprisingly wide variety of uses for indigenous words have been suggested in naming books. In $1914 \mathrm{E}$ I Watkin recognised the trend of using Aboriginal names for 'townships, residences, properties, steamers and yachts' ${ }^{20}$ Others made some less obvious suggestions: F D McCarthy suggested that indigenous names could be used for 'reserves, clubs ... and commercial products,' while H M Cooper suggested both 'institutions' and 'commercial products'.21 Perhaps the most interesting suggestions came from Rex Ingamells, founder of the Jindyworobak literary movement. Amongst his list of uses that he believed to be already common in Australia were guest-houses, patents, literary magazines and aeroplanes. He added the suggestions of stations, business enterprises and also children's names, reporting 'I know a small white girl who bears the pretty native name of Birrahlee.' Ingamells was clearly convinced that indigenous names had many potential uses for the white Australian: '[i]t seems to me that the potential interest of our native words for present application has still barely been touched. To what imaginative lengths might not a schoolboy go in fixing upon appropriately mischievous nick-names!'22

While Ingamells' attitude to the possible uses of indigenous names is perhaps a little extreme, it is ultimately fairly typical of the genre. He did not believe that there were any ethical dilemmas involved in the appropriation of indigenous names and argued that: '[s]ince most Australian Aboriginal speech has passed for ever, never to be spoken again in proper dialect, here are simply memorials that may be freely used and may fitly lend colour to our transplanted European life in this country. ${ }^{23}$ No naming book suggests any restriction to the way in which Aboriginal words should be used. Although there is some variety in attitude regarding which words are appropriate, each book suggests explicitly or implicitly that indigenous words are free to be used in any way that the reader pleases.

Aboriginal names have often been described as pleasant sounding, melodious or euphonious. Where naming books are concerned, this has almost always been the case. Endacott's reference to 'musical native aboriginal names' and 'pleasant sounding words' was the first in a long line of naming book references to the perceived aesthetic value of indigenous words. The emphasis that most naming books place on the attractiveness of Aboriginal words in most cases also results in the word selection for that book being biased towards words that are supposedly 'euphonious' or 'pleasant sounding'. The perceived attraction of indigenous words was deemed more important than their cultural context.

Keith Kennedy wrote in his foreword to James Tyrrell's Australian Aboriginal Place Names (1933) that "before the coming of the white man every feature of 
Australia was known to its native owners, and had an appropriate name in one or other of the dialects of their melodious language'. ${ }^{24} \mathrm{~F} \mathrm{D} \mathrm{McCarthy}$ of the Australian Museum goes as far as using the word 'Euphonious' in the title of his book. Interestingly however, he makes the observation that in Australia there were hundreds of tribal languages, some of which were euphonious and others harsh and ugly'. ${ }^{25}$ McCarthy does not make it clear whether or not he has omitted the 'harsh and ugly' sounding words on the basis that they would contradict his title.

H M Cooper was another notable champion of the euphonious indigenous word. He partly attributed the popularity of indigenous words to 'the attractiveness of the wealth of words, so beautiful in sound.' Unlike McCarthy, Cooper also makes it abundantly clear that the way the words sounded was very important to the selection criteria for his book: "[e]very endeavour has been made to confine the list of words to those which are easy to pronounce, pleasant to the ear and at the same time reasonably short, in order to avoid clumsiness. ${ }^{26}$ Cooper goes on to explain the circumstances in which a 'harsh' or 'ugly' word may be used: '[s]ome words, not necessarily euphonious but of general interest, such as the names of certain ceremonies, local fishes and so forth have been included.' Cooper was committed to providing a list of words that was accessible to the public. Consequently, apart from these words of 'general interest,' all words had to be euphonious. He also ensured ease of use by employing standardised systems of spelling only where the resultant spelling was 'easy to pronounce and its use involves no difficulties.' The issue for Cooper was clearly accessibility, and in this respect his attitude is typical of the genre.

An important (and misleading) implication of the way in which naming books typically present themselves is that there is only one Aboriginal language. The earliest popular naming books of Watkin and Endacott make virtually no reference to the variety of languages spoken by the indigenous people of Australia, such that an uninformed reader could be forgiven for believing that there was only one Aboriginal language. It would be ludicrous to suggest, however, that Watkin and Endacott were not aware of the diversity of Aboriginal languages. A more accurate conclusion would be that they believed this diversity was not an important consideration when searching for a potential house name and that no distinction between languages needed to be drawn in this context.

The examples of Watkin and Endacott aside, most naming books made at least some reference to the diversity of languages from which their lists were derived. Some even went as far as indicating the origin of each word within the body of the wordlist. Justine Kenyon, in The Aboriginal Word Book, stressed the differences between individual 'dialects' of the Aboriginal 'language'. Accordingly, she divided these 'dialects' into ten different regions covering the whole of Australia. ${ }^{27}$ Although these boundaries where somewhat arbitrary and defined in European terms, it was for its time a more accurate approach. Kenyon believed that such divisions were useful because they meant that in choosing a name for one's home, locality as well as meaning may be considered.' 28 Other naming books categorised indigenous words in similar ways. Reed's Aboriginal Words of Australia indicated from which state or territory each word was derived and added the eighth category of "Central Australia. ${ }^{29} \mathrm{~F} \mathrm{D} \mathrm{McCarthy}$ was more thorough and 
divided New South Wales into sixty-eight tribal regions. He indicated where possible from which tribe each word came. It is important to note, however, that none of these books arranged the order of their word lists according to the etymology of the words. They were all arranged alphabetically, some of them dividing the list into sections which related to the words' meanings but not linguistic origins. These categories were aimed at assisting the choice of an appropriate house name. If regional derivation was included, it was typically indicated by way of a coded letter or number after each alphabetically arranged word.

Although Justine Kenyon hinted at the possibility of using words of regional significance, she did not suggest that this was essential. Moreover, no other naming book makes such a suggestion. The key result of the naming books' tendency to bundle all indigenous words together was that the words lost their cultural and linguistic context. Each word became an 'Aboriginal word' - the word's language and the complexity of its meaning were lost. It is clear that the compilers of naming books did not often see it as necessary to preserve knowledge of the diversity of Aboriginal languages. To them, any word was appropriate as long as it was 'Aboriginal'.

Ingamells offered the following justification for bundling linguistically diverse indigenous words into the same indiscriminate word list:

I feel that no other excuse is needed for presenting, cheek by jowl, words spoken of old in particular segregation of such areas as Amhem Land, Cape York Peninsula, Gippsland, the Murray River, the Swan River, the MacDonnell Ranges. It is not to the purpose here to trace exact tribal sources of words and only the broadest regional indications are provided in the accompanying key. ${ }^{30}$

Robert Sellick has identified this approach in the Jindyworobaks' use of Aboriginal words in their poetry: 'The failure of the Jindyworobaks to identify a precise linguistic origin ... calls into question the nature of the 'Aboriginality' they are presenting. The language is non-specific, unlocalised ... It is as though the Aborigines are denied an individual voice. 31

The only naming book that departs from this misleading approach is Macquarie Aboriginal Words, published in 1994. Compiled by a team of linguists, this refreshing book sought to portray Aboriginal words as part of actual languages rather than as part of an arbitrary wordlist:

Words have not been selected (as in the earlier wordlists) on the basis of sounding 'pleasant' or being easy to pronounce for an English speaker, because this would give the false impression that Australian languages have only such euphonious words. Rather, they have been selected more to give some small inkling of the character of the languages. ${ }^{32}$

The book successfully conveyed the message that there was (and is) considerable diversity in Aboriginal languages and that the notion that there is only one Aboriginal language is very misleading. Moreover, it affirmed that Aboriginal words are not distinct entities but are part of rich and complex languages, which can provide an insight into rich and complex cultures. The authors concentrated on seventeen Australian languages from various regions and presented (as best they could) a summary of each language. 
The book received wide acclaim. One critic suggested that 'after the Macquarie Aboriginal Words, there will never be another excuse for the ignorance of oversimplification'. ${ }^{33}$ Given this praise, it is unfortunate that two years later Macquarie publishing committed the same sin of oversimplification. Clearly the publishers were well aware of the potential market for another more typical naming book, so they drew a sample of words out of Macquarie Aboriginal Words to produce The Macquarie Aboriginal Naming Book: An Australian Guide to Naming your Home or Boat. In this publication, the words were no longer arranged according to language but according to twenty-six categories such as 'Water' and 'Trees'. The introduction explains that:

if there is something specific about your home or surroundings that you want to bring into its name, go straight to the category in which that feature will be included. For example, if your house is built next to a lake, you could look in Section 3, which is Water. ${ }^{34}$

The end result was that the words once again lost their linguistic context and became discrete words, rather than elements within a language. In essence, this arrangement of Aboriginal words is no less ridiculous than would be a list of 'European words,' which bundled together English, French, German, Italian and Spanish words under the same heading. The second Macquarie publication was an unfortunate step back after such a worthwhile step forward.

As with the question of language diversity, the authenticity or otherwise of the words contained within naming books has been approached in a variety of ways. Some compilers or publishers have been inclined to assert the authenticity of their words, while others have emphasised the difficulty involved in finding reliable transcriptions of Aboriginal words. This contrast is interesting, and is one of the key ways in which naming books differ in their nature and overall approach. Justine Kenyon's Aboriginal Word Book contained the following rather enthusiastic endorsement of its contents:

The words in this book can be implicitly relied upon. They are the authentic translations by experts of [A]boriginal words ...

If you want an [A]boriginal word for the name of your house, see that you get one with a meaning you can trust.

The meanings in this book are authentic and can be relied upon. ${ }^{35}$

Whether this was just publisher's rhetoric or the author really believed in the 'authenticity' of the words is unclear. In any case, it is a rather empty assertion. When an Aboriginal word is appropriated and used in a non-indigenous context, the whole notion of it being authentic or not is largely irrelevant. It is true that some words retain more of their original meaning than others, but the act of using an Aboriginal word in a non-Aboriginal context ultimately compromises its authenticity. This fact has not gone unrecognised in naming book publications. McCarthy recognises how much of a word's actual meaning is lost when it is appropriated:

It is not claimed that the meanings are scientifically accurate. Most of the words were recorded by missionaries, officers of government departments such as the police, surveyors, and registrars, and by people interested in the natives, few of whom had any linguistic training for such specialized work. Explanations often fail 
to convey the variety of meanings that words may have, especially where it is connected with the sacred, legal, or social aspects of [A]boriginal life. Many of the recorders knew little about the spiritual beliefs of the Aborigines, and as a consequence gave too narrow an interpretation to words and phrases expressive of their secret life. ${ }^{36}$

McCarthy highlights here another of the key consequences of the appropriation of Aboriginal words. Just as bundling diverse indigenous words together in the same list obscures their linguistic diversity, the use of indigenous words out of context with simple or even poetic translations obscures the complexity of meaning that these words must have had within their cultural context. In his introduction, McCarthy quotes A P Elkin (his former teacher) in recognition of this fact:

[Language] is not a tool used by the culture, but a living functioning element within it. The meanings of its words and the forms of its structure are intimately related to the cultural contexts in which they find a place; and contexts, on their part, are made of actions, presuppositions, beliefs and mutual understanding. ${ }^{37}$

Although McCarthy recognised the importance of these issues, naming books rarely promote an understanding of Aboriginal language beyond a very superficial level. They promote the use of tiny fragments of language, which lose so much of their meaning when considered out of context. To understand the reasons behind this, we must consider what purpose the words serve after their appropriation. When we consider this, we see that their use has much more to do with aesthetics and Australian nationalism than it has to do with original meanings, authentic or otherwise.

Although the success of the naming book genre owes much to the perceived attractiveness of 'euphonious' indigenous words, a more crucial factor underpinned the appropriation of indigenous words. The most common theme of all the naming books is national identity. Indigenous words have been (and continue to be) seen as 'Australian' words. Endacott believed that the use of Aboriginal words would assist 'the growth of a distinct national feeling. ${ }^{\text {'38 }}$ This sentiment was echoed in many other naming books. McCarthy believed that Aboriginal words 'are Australian and should form an element in our national culture' ${ }^{39}$ Cooper was a little more oblique, but the nationalist sentiment is present:

The increased use in recent years of words, handed down to us by our Australian Aborigines ... appears to be due to ... the awakening of a genuine desire to adopt them in the knowledge that by so doing the users are strengthening, even in a small way, our memory of the former occupants of Australia. ${ }^{40}$

Although this extract suggests many other underlying motives it implies that the Aboriginal words are part of Australia's 'heritage.' The Macquarie Aboriginal Naming Book seemingly casting aside every hint of the linguistic and cultural sensitivity of its predecessor, makes its nationalistic program only too clear:

Rather than harking back to their often European roots, many Australians are seeking names which reflect the distinctive character of the Australian landscape, and Aboriginal and Torres Strait Islander languages are an obvious and wealthy store of such names. ${ }^{41}$ 
These obvious appeals to national identity are supported by a variety of more subtle examples of nationalistic sentiment and motivation. Naming books produced by museums inevitably inherited the sense of nationalism that is inherent in the museum project. In many cases, nationalism is evoked by an implied sense of ownership of indigenous words. At other times, a connection between Aboriginal words and Australian flora and fauna is implied. Aboriginal words have also been seen as one of the keys to reconciling the essentially British nature of.Australian society with the decidedly un-British environment that society inhabits.

Two of the naming books discussed in this article were published by museums. Both Cooper and McCarthy (the two compilers) had backgrounds in Australian archaeology. In fact, Cooper was far better known as a collector of archaeological relics than as a collector of Aboriginal words. ${ }^{42}$ Similarly, the back cover of McCarthy's book on Aboriginal names included the following plea:

We appeal to our readers to assist in the campaign for the preservation of aboriginal relics ... Unfortunately, much destruction has been done to these national treasures through ignorance, vandalism, and over-zealous collecting. They are of great scientific and historical importance and the sole remaining clues to the prehistory of Australia. For these reasons it is the responsibility of every citizen to assist in their preservation. ${ }^{43}$

A central task of the museums of this period was the 'documentation' of Aboriginal culture. The social Darwinist paradigm of an evolutionary hierarchy of cultures specified that, in studying 'stone-age' Aboriginal culture, archaeologists were essentially studying the pre-history of the human species. In his naming book, Cooper expresses this ideology well when he speaks of the 'primitive stone age' culture of 'our natives': 'Their way of life ... indicates that they belonged to the class of primitive man termed Food Gatherers and not Food Producers such as we who at a later period succeeded them. ${ }^{44}$ For museum curators, however, Aboriginal culture not only represented a key to the prehistory of the human species; it also gave an insight into the prehistory of Australia, and it is here that the museum's nationalist programme becomes clear. McCarthy argues that Aboriginal words 'are Australian and should form an element in our national culture.' Just as museums collected specimens of Australian flora and fauna to document Australia's natural history, McCarthy's collection of Aboriginal words suggests similar motives. He talks of Aboriginal words in the past tense - 'there were hundreds of tribal languages' - and states that 'their use will contribute to a better understanding of the people.' It is assumed that by this he means an understanding of 'ancient' Aborigines, rather than of those who still live and struggle in twentieth century Australian society. ${ }^{45}$

The nationalistic motive behind these museum publications is most clearly illustrated by their sense of ownership of indigenous heritage. In discussing Aboriginal culture, Cooper refers to 'our natives', while McCarthy's assertion that Aboriginal words are 'Australian' also expresses possession. This theme of ownership is prominent in other naming books: Reed notes that 'Australia possesses a heritage of place names which pay tribute to the lively imagination of her Aboriginal inhabitants'; while Ingamells puts the question of ownership beyond a doubt, saying that "it is a list for the entertainment and use of modern 
Australians who feel sufficient interest in the original Australians to delight in these echoes from their speech.' 46

Most importantly, the tendency of these naming books to idealise 'ancient' Aboriginal culture freezes Aboriginal culture in time, and denies modern Aboriginal people their identity. In 1965, AW Reed noted that:

It is a tragedy that the meanings of so many of the names have never been recorded. It is too late to do so now, for the tribesmen have passed to the home of their ancestral spirits or, if they are left, have little knowledge of the traditions of their own people. ${ }^{47}$

While at one level these comments recognise the fact that most Aboriginal tribes were devastated by invasion and removed from their traditional lands, the comments also have the result of denying Aboriginal people the right to live amongst Europeans; as though, somehow, their contact with Europeans destroys their authenticity, and that to be Aboriginal they must paint their faces with ochre and carry a spear. ${ }^{48}$

The relationship between naming books and museums tells us much about these books' nationalistic motives. Another important connection is with the Jindyworobak movement. The fact that Rex Ingamells produced a naming book himself indicates just how neatly the popular use of Aboriginal names fitted in with the Jindyworobak programme. In his seminal Jindyworobak statement, Conditional Culture, Ingamells is principally concerned with differentiating Australian art from English art:

A fundamental break ... with the spirit of English culture, is the prerequisite for the development of an Australian culture. Without the fact of ultimate individuality, separate identity, any general sense of culture in any country must be misty and anaemic ... Its quintessence must lie in the realization of whatever things are distinctive in our environment and their sublimation in art and idea, in culture. ${ }^{49}$

Ingamells plea for 'Environmental Values' was ultimately a plea for Australian artists to express themselves artistically in relation to the Australian environment:

I cannot deplore too vehemently the dangerous habit of using figures of speech with regard to essentially Australian things which call up such a flood of Old World associations as to gloze [sic] over all distinctiveness. It has been a piteous custom to write of Australian things with the English idiom, an idiom which can achieve exactness in England but not here. ${ }^{50}$

To develop an Australian idiom, Ingamells believed that 'writers and painters must become hard-working students of [A]boriginal culture. ${ }^{51}$ His reasoning was that Aborigines were already in tune with their environment and able to express themselves artistically within that context. Of Aboriginal art, he argued that in the finest flowerings of their arts of poetry, drama and painting, they showed themselves masters in sublimating with pristine directness and unselfconsciousness the highlights of their primaeval life. 52

The most crucial thing to recognise about the Jindyworobak philosophy was that it was directed at non-indigenous Australians. Literary critic Brian Elliot identified that 'the Aboriginal element in the Jindyworobak programme ... was not part of any impulse to write Aboriginal history or to propound Aboriginal law or morality, or even to describe Aboriginal culture ... their mission was directed not 
to the blacks, but to the whites. ${ }^{53}$ Terry Goldie has argued that the key reason for the use of Aboriginal culture by the Jindyworobaks was 'to 'indigenize' the text.' 54 For this reason, the Jindyworobaks' approach is easily described as cultural appropriation. As Sellick has pointed out, the Jindyworobaks' choice of a name (which means 'to annex or join') 'carries with it the sense of appropriation - the taking over, by the descendants of the original white settlers, of Aboriginal language, culture and history. 55

The version of Aboriginality that Ingamells sought to promote was grounded in the social Darwinist thought that still dominated popular opinion and government policy in the 1930s. The culture of contemporary Aborigines was irrelevant to Ingamells' project. He saw value in 'ancient' Aboriginal culture but believed that this noble ideal was long since lost. He argued 'the blacks that remain are a degenerate puppet people, mere parodies of what their race once was.' 56 In appropriating Aboriginal culture, Ingamells was only really interested in a certain idealised version of Aboriginal culture which suited his purposes. In particular, Spencer's and Gillen's work The Arunta and James Devaney's The Vanished Tribes had an influence on Ingamells and the other Jindyworobaks. ${ }^{57}$ They drew (selectively) from these works in order to construct a version of Aboriginal society which had little connection with reality. ${ }^{58}$ Ingamells' naming book, and the naming book genre generally, are very similar in all these ways to the Jindyworobak movement: a perfect example of the appropriation of indigenous culture (in this case language) to construct a unique Australian identity.

Endacott's loosely defined 'distinct national feeling,' which he believed was fostered by the use of Aboriginal house names, is an early example of the nationalistic thinking that found more detailed expression in later naming books. Aboriginal naming books display this tendency to use Aboriginal words for nationalistic purposes. Naming books simplify and romanticise Aboriginal words and remove them from their cultural and linguistic context. In Cooper's and McCarthy's publications, the collection and presentation of Aboriginal words can be likened to the collection and presentation of the Aboriginal 'relics' which were on display in the Museums of the time. Their books are thus linked to the Social Darwinist paradigm of a hierarchy of cultures. For Ingamells, Aboriginal words were a means of indigenising the text, whether that text was a suburban house, or a poem, or a short story.

The presumption that Aboriginal words are readily applicable to a suburban house is evidence that Aboriginal names have been subject to a process of cultural appropriation that can subsume their complexity of meaning and association. Hundreds of languages have been merged under the convenient heading of 'Aboriginal words' and any sense of their original linguistic and cultural richness is lost as a result. This superficial appropriation of Aboriginal words and place names is a symptom of white Australia's simplified and idealised understanding of Aboriginal culture. It exemplifies how Aboriginal culture can be shallowly employed to indigenise Australian national identity. 